\title{
РАЗДЕЛІІІ. ПЕДАГОГИКА
}

\author{
Bessarabova I.S., Liu Tse \\ The role of vocal art in Patriotic education of students in China
}

Volgograd state socio-pedagogical University

(Russia, Volgograd)

doi: $10.18411 / s r-10-10-2018-06$

idsp: 000001:sr-10-10-2018-06

\section{Abstract}

China is the oldest civilization. Its experience in educating the young generation in this regard requires special reflection today. The purpose of this article is to analyze the features of patriotic education of young people by means of vocal art in modern China.

Key words: patriotic education, vocal art, solidarity and unity of the Chinese nation, education of active civil position of students, moral and aesthetic development in the lessons of vocals, spiritual heritage of the country.

Patriotism is one of the main values of any nation and state, but in China patriotism acquired a special form of expression after the formation of People's Republic of China (PRC) in 1949, and became the basis for the development of "socialism with Chinese specificity". The strengthening of the national spirit is an essential condition for the preservation of the solidarity and unity of the Chinese nation, as it accelerates the realization of the "Chinese dream", which is to be realized by 2049. This is what XI Jinping said in 2012 as a new leader in his first public speech, and for the first time he set the Chinese people a long-term development goal. At the same time, XI Jinping called for the education of patriotism among young people to achieve the great revival of the Chinese nation. Since 1994, the Central Committee of the Communist party of China (CPC Central Committee) began to pay close attention to patriotic education in the country, and today the patriotic education of Chinese youth has become a matter of national importance.

In October 2017, a new law on Patriotic education came into force in China, and now students of junior and middle classes are obliged not only to learn the text and sing the national hymn, but also to learn in detail its history and rules of performance. As reported in the Chinese edition of China Daily, such measures will help to maintain a sense of love for the country in the modern world and increase awareness of Chinese youth about patriotism [8].

Patriotic education in China is carried out at all levels of education - in kindergarten, secondary and higher school. The important role of patriotic education of citizens is fixed by the legislation. Thus, in the Constitution of the PRC, article 24 states that the state defends such civic virtues as love for the Motherland, people, labor, science, socialism; it educates the people in the spirit of patriotism, collectivism, internationalism and communism, as well as dialectical and historical materialism to fight against bourgeois, feudal and other corrupting ideology [1].

In the PRC Law on education of 1995 in article 6 it is emphasized that the state should impart to the pupils such qualities as patriotism, collectivism, loyalty to the cause of socialism; clarify the meaning of concepts about the ideas of the legal system of the state, about the national defense of the country, on the principles of the unity of the nation [3].

In the PRC Law on higher education of 1999 in article 53 it is pointed that the students of higher educational institutions must comply with laws and regulations, the student code of conduct, respect teachers, study hard, strengthen their health, support the ideas of patriotism, study Marxism-Leninism, the ideas of Mao Zedong and theory of Deng Xiaoping, be moral and strive to possess a high level of scientific and cultural knowledge and specialized skills [2]. 
Patriotic education is one of the most important ideas of Chinese pedagogy and involves the education of the Chinese spirit, respect and observance of Chinese traditions. Chinese people from early childhood are brought up as patriots not only of their country, but also of their hometown, or other place where they were born. Every Chinese person is obliged to know information about the size of the territory of his country and his native province, the number of people living there; know the basic principles of the Constitution, the history of the CPC, the new laws adopted by the government. In the materials of the modern Chinese press it is noted that today in China the main slogan is not the construction of a Communist society, but the idea of "the great revival of the Chinese nation", which should be deeply rooted in the minds of the younger generation. Socialism is no longer perceived as a goal, but as a means of ensuring the greatness of the nation, and patriotism is called "the best tradition and the highest moral quality of the Chinese nation" [5].

The well-organized work of the teacher in the vocal class carries great potential in the process of education of active civil position of students, as vocal art has a strong emotional, aesthetic and moral influence on a person. Vocal art is inseparable from the spiritual and moral development of a person, as it affects emotionally the spiritual world of a person, evokes inner feelings and contributes to the education of moral and patriotic qualities through understanding the content of a musical work. The main direction of the formation of patriotism among Chinese students in the process of vocal training is acquaintance with the samples of national musical art. Chinese teachers believe that it is impossible to educate patriots of the country without the use of the rich potential of the ancient folk music of China, since Chinese folk music has a pronounced national character, it is part of the Treasury of Chinese culture.

Chinese teachers note the difficulty of preserving the national musical art in modern conditions, as young people in China, as well as in other countries, are fond of modern dance rhythms and songs. In the era of globalization in China many genres of Western European and American music - rock, hip-hop, rap - began to spread. Despite this, according to Zhang Jun, it is in China, as in no other country in the world, where musical national art is very well preserved. During national holidays, folk music is played and old folk songs are sung. The Chinese have beautiful voices and good hearing [10].

Since vocal art is a mass form of creativity, teaching children singing is the best way to introduce them to their native culture. As Qin Qin stressed in his study, the lessons of vocal teacher must solve the following problems through the competent selection of repertoire: to develop aesthetic feelings of students; to motivate them to participate in the creative life of their native city or village; to cultivate a sense of love and respect for the small homeland and the country, which will eventually contribute to the formation of Patriotic feelings and qualities of students. According to the scientist, the best environment for patriotic education of children is the atmosphere created by the vocal team. This environment includes people united by a common favorite occupation, helps to create an atmosphere of friendship and mutual support, causes the desire to achieve their goals jointly, which ultimately helps every child to socialize in the team [6].

Another researcher Liu Jin also believes that the effectiveness of solving educational problems in vocal lessons is largely determined by the correct selection of repertoire. In this case, the teacher must take into account the degree of complexity of the material, focus on the abilities of their students and the level of preparedness. Patriotic education can not be separated from the moral and aesthetic development in the lessons of vocals, as music forms emotional responsiveness, helps to develop artistic taste, teaches to appreciate the beauty, to understand and respect the spiritual wealth of the native country, expands the musical horizons of students through acquaintance with the works of outstanding artists who have made an invaluable contribution to the development of musical education in China [4].

Students' compulsory knowledge of the history of vocal performance formation in China is emphasized in the study of Zhao Feilong, as young citizens should have an idea of famous personalities and their contribution to the Treasury of national and world culture. True patriots, 
according to the scientist, should know, respect, love and be proud of the spiritual heritage of their country. Zhao Feilong emphasizes that the singing art of China has a rich centuries-old history, but only at the beginning of the XX-th century it ceases to be exotic for Europeans. The specificity of the Chinese vocal school is that the art of singing, for many historical reasons, has long been in a closed cultural space, and only in the last century made a breakthrough in the center of the world's artistic achievements [11].

Jan Bo points to the important educational role of concert activity in his research. Since the concert is the result of the work done, it shows the achievements of the vocal group, forms the responsibility of each participant to the team, teacher, audience. According to the scientist, the collective performance of songs of appropriate content during national holidays or other cultural events is especially valuable in the process of patriotic education. In the process of performance the participants are united by a common idea, they strive to convey to the listener the feelings, the beauty of the melody and the importance of the words of the song. Understanding that they act as a single whole, and that joint efforts give the song strength and expressiveness, has a powerful emotional and psychological impact on the members of the choir. Heartfelt and sensual performance of songs about the Motherland, the words of which are clear and close to everyone, gives them a sense of faith in a bright future, pride in the exploits of their ancestors [9].

A significant role in the education of patriots of the country by means of vocal art, according to ShenFanfan, is played by the head of the choir, who is not only obliged to combine professionally different methodological techniques in teaching children vocal, but also to captivate every child with music so that it evokes emotions and encourages reflection. This is possible only if children have a need to communicate with vocal music. To do this, it is necessary to create and maintain a special lively and joyful atmosphere during the classes, so that every child feels joy from his own achievements and feels his significant role in the overall success of the team, which performs a very important mission in the common cause of unity of the nation by the power of art. Then, as ShenFanfan emphasizes, the emotional and sensual perception of the songs performed by children will contribute to the formation of life values and in the future will be embodied in actions. The teacher must remember that children feel keenly any mood of their teacher, so the importance of professional functions of the choir Director is difficult to overestimate, as children trust their teacher sincerely and consider him a role model. Educational work should be a single musical and pedagogical process, in which the most acceptable style of communication between teachers and students should be a combination of rigor and goodwill [7].

Summarizing the above mentioned, it should be noted that the pedagogical potential of vocal education in the patriotic education of students is recognized by all Chinese scientists, whose work results served as the material for this article. We highlight the main points that are emphasized by the researchers in educational work:

- using the rich potential of ancient Chinese folk music to instill love for national musical traditions and the spiritual heritage of the Chinese people;

careful selection of the song repertoire of patriotic orientation, taking into account the degree of complexity of the verbal and musical material for specific performers, allowing to solve educational problems, combining patriotic education with moral and aesthetic development;

- using the developing and educating potential of the vocal team, creating an atmosphere of creative activity in the classroom, passion for the common occupation, mutual assistance and responsibility for the common success;

expanding the musical horizons of students through acquaintance with the best examples of folk and modern music, as well as the history of the formation of vocal art in China, educational activities of outstanding musicians and 
performers who have contributed to the development of music education in the country;

- organization of the concert performances of students to make everyone feel responsible for the common occupation, as well as experience the joy of personal achievements;

- continuous improvement of the level of professional training of vocal teachers and heads of choral groups.

$$
* * *
$$

1. Constitution of the People's Republic of China [Электронныйресурc]. URL: http://www. npc.gov. cn/englishnpc/Constitution/2007-11/15/content_1372963.htm (датаобращения: 24.09.2018).

2. Higher Education Law of the People's Republic of China [Электронныйресурc]. URL: http://www.china.org.cn/english/education/184667.htm (дата обращения: 24.09.2018).

3. Law of China on education [Electronic resource]. URL: https://asia-business.ru/law/law3/education/ (accessed: 20.09.2018).

4. Liu Jin. Opera culture of modern China: the problem of training performers: Dis. ... cand. ofped. sciences: 13.00.02: St. Petersburg, 2010-173 p.

5. National idea of China [Electronic resource]. URL: http://rossiyanavsegda.ru/read/812/ (accessed: 22.09.2018).

6. Qin Qin. Liu Shikun, Zhou Guangen and Zsuzsa: three faces of contemporary art music of China: Dis. ... cand. of art history: 17.00.02: St. Petersburg, 2013-165 p.

7. ShenFanfan. Interaction of teacher and student in the musical and pedagogical process: in the context of the development of works of composers of the People's Republic of China: Dis. ... cand. ofped. sciences: 13.00.02: M., 2011-163 p.

8. The new law on Patriotic education entered into force in China [Electronic resource]. URL: https://news.rambler.ru/other/38110719-novyy-zakon-o-patrioticheskom-vospitanii-vstupil-v-silu-v-knr/ (accessed: 22.09.2018).

9. Yang Bo. Dynamics of development of professional solo singing in China: education, pedagogical and performing principles: Dis. ... cand. of art history: 17.00.02: Nizhny Novgorod, 2016-186 p.

10. Zhang Jun. Chinese folk music in professional training of students of musical departments: Dis. ... cand. ofped. sciences: 13.00.02: M., 2008.-140 p.

11. Zhao Feilong. Formation of concert vocal performance in China in the 20-30s of the XX century / Zhao Feilong //Diploma. 2017. № 12 (86).- P. 196-198.

\section{Маеркина Е.B. \\ Влияние мотивации достижения на формирование навыков саморегуляции в познавательной активности старшеклассников}

Оренбургский Государственный Университет

(Россия, Оренбург)

doi: $10.18411 / s r-10-10-2018-07$

idsp: 000001:sr-10-10-2018-07

\section{Аннотация}

В статье рассматривается взаимосвязь между мотивацией достижения успеха и способностью старшеклассников к самоорганизации своей деятельности.

Старшеклассники, ориентированных на успех, выделяют на более высоком уровне значимые условия на достижение целей как в текущей ситуации, так и в перспективе, при смене способны гибко перестраивать свои планы, вносить коррективы в регуляцию и наиболее успешно и активно решать поставленную учебную задачу.

Ключевые слова: познавательная активность, мотивация достижения, навыки саморегуляции.

Одной из важных задач модернизации современного образования в школе становится развитие ученика как субъекта учения, активно, осознающего важность обучения и самообучения для своего успеха в жизни, а также овладевающего 